\title{
Cytotoxic, Genotoxic, and Polymorphism Effects on Vanilla planifolia Jacks ex Andrews after Long-Term Exposure to Argovit ${ }^{\circledR}$ Silver Nanoparticles
}

\author{
Jericó Jabín Bello-Bello ${ }^{1, *}$, José Luis Spinoso-Castillo ${ }^{2}$, Samantha Arano-Avalos ${ }^{2}$, \\ Eduardo Martínez-Estrada ${ }^{2}$, María Evarista Arellano-García ${ }^{3}$ D , Alexey Pestryakov ${ }^{4}$, \\ Yanis Toledano-Magaña ${ }^{5}$, Juan Carlos García-Ramos ${ }^{5, *(D)}$ and Nina Bogdanchikova ${ }^{6}$
}

1 Conacyt-Colegio de Postgraduados Campus Córdoba, Carretera Córdoba Veracruz, Amatlán de los Reyes Km 348, Veracruz 94946, Mexico

2 Colegio de Postgraduados Campus Córdoba, Carretera Córdoba Veracruz, Amatlán de los Reyes Km 348, Veracruz 94946, Mexico; jlspinoso@gmail.com (J.L.S.-C.); samy.a.avalos@gmail.com (S.A.-A.); eduagrom@hotmail.com (E.M.-E.)

3 Facultad de Ciencias, Universidad Autónoma de Baja California, Carretera Transpeninsular Tijuana 3917, Ensenada 22860, Mexico; evarista.arellano@uabc.edu.mx

4 Research School of Chemical and Biomedical Technologies, Tomsk Polytechnic University, Lenin Avenue 30, Tomsk 634050, Russia; pestryakov2005@yandex.ru

5 Conacyt-Universidad Nacional Autónoma de México-Centro de Nanociencias y Nanotecnología, Carretera Tijuana-Ensenada Km 107, Ensenada 22860, Mexico; yanistoledano@cnyn.unam.mx

6 Centro de Nanociencias y Nanotecnología, Universidad Nacional Autónoma de México, Carretera Tijuana-Ensenada Km 107, Ensenada 22860, México; nina@cnyn.unam.mx

* Correspondence: jericobello@gmail.com (J.J.B.-B.); jcgr@cnyn.unam.mx (J.C.G.-R.); Tel.: +52-271-716-6000 or +52-271-716-6057 or +52-271-716-6055 (J.J.B.-B.); +52-646-175-0650 (J.C.G.-R.)

Received: 15 July 2018; Accepted: 20 September 2018; Published: 25 September 2018

check for updates

\begin{abstract}
Worldwide demands of Vanilla planifolia lead to finding new options to produce large-scale and contaminant-free crops. Particularly, the Mexican Government has classified Vanilla planifolia at risk and it subject to protection programs since wild species are in danger of extinction and no more than 30 clones have been found. Nanotechnology could help to solve both demands and genetic variability, but toxicological concerns must be solved. In this work, we present the first study of the cytotoxic and genotoxic effects promoted by AgNPs in Vanilla planifolia plantlets after a very long exposure time of six weeks. Our results show that Vanilla planifolia plantlets growth with doses of 25 and $50 \mathrm{mg} / \mathrm{L}$ is favored with a small decrease in the mitotic index. A dose-dependency in the frequency of cells with chromosomal aberrations and micronuclei was found. However, genotoxic effects could be considered as minimum due to with the highest concentration employed (200 mg/L), the total percentage of chromatic aberrations is lower than $5 \%$ with only three micronuclei in 3000 cells, despite the long-time exposure to AgNP. Therefore, 25 and $50 \mathrm{mg} / \mathrm{L}$ (1.5 and $3 \mathrm{mg} / \mathrm{L}$ of metallic silver) were identified as safe concentrations for Vanilla planifolia growth on in vitro conditions. Exposure of plantlets to AgNPs increase the polymorphism registered by inter-simple sequence repeat method (ISSR), which could be useful to promote the genetic variability of this species.
\end{abstract}

Keywords: silver nanoparticles; Vanilla planifolia; growth promotion; cytotoxicity; genotoxicity; polymorphism induction; safe nanoparticles 


\section{Introduction}

Vanilla planifolia is the source of vanillin, a widely used raw material of the pharmaceutical, food, and cosmetic industry. This poses some challenges, like the large-scale and contaminant-free cultivation of this species to meet the growing requirements of the industry [1]. Usually, it is propagated asexually by cuttings, which does not guarantee the health of the new plantations. An alternative to avoid these difficulties emerges with the combination of nanotechnology and plant tissue culture (PTC), which is useful for manipulation, conservation, and regeneration of plants [2,3].

Recently, the application of silver nanoparticles (AgNPs) in PTC has been raised due to their capacity to eliminate the microorganisms that affect crops [4,5]. Particularly, explant disinfection protocols during in vitro establishment [6,7] with AgNPs produce very good results. However, major concerns appear regarding toxicological and environmental effects which must be solved before AgNPs' indiscriminate and spreading use [8,9]. As adverse effects manifest strongly depending on plant sensitivity, the identification of safety windows for AgNPs use in each species is highly recommended. Some examples of problems produced by the use of higher amounts of AgNPs are the slow growth of vanilla, poplars, and Arabidopsis, or the decrease of mung bean seed germination. [1,10,11].

Most of the toxicological effects produced by exposure of plants to AgNPs considers physiological endpoints, such as number and length of shoots and roots or biochemical markers as reactive oxygen species (ROS) concentration. However, much more effort must be designated in the evaluation of genetic endpoints, monitoring chromosomic aberrations, the appearance of micronuclei, DNA damage, chromatid exchanges, among others [12]. To achieve this goal, several DNA-based techniques like Inter-Simple Sequence Repeat (ISSR) [13] or amplified fragment length polymorphism (AFLP) [14] are employed, with the advantage that both techniques also help in the identification and quantification of polymorphism.

Last year, our group reported the efficacy of the AgNPs' commercial formulation to eliminate contaminants from Vanilla planifolia plantlets through a temporary immersion system that is going to be used on in vitro regeneration procedures. In this work 30 days of exposure to concentrations higher than $50 \mathrm{mg} / \mathrm{L}$ generates adverse effects in the development of plantlets, mainly by the high increase of ROS induced by the nanoparticles that overwhelmed the antioxidant response of the plant. Continuing with the current work will help to enhance the knowledge regarding beneficial and adverse effects of the use of AgNPs in plants.

In this work, we studied the cytotoxic and genotoxic effects on Vanilla planifolia plantlets exposed to different concentrations of AgNPs for six weeks, two weeks more than the past study. We evaluate the mitotic index of treated plantlets compared to negative controls and the potential genotoxic effect determining the frequency of chromatic aberrations appearance (bridges, budges, chromosomal fragments and micronuclei) on plantlets exposed to this AgNPs formulation. Furthermore, for the safe concentrations, we explore the capacity of this AgNPs formulation to improve the genetic variability through the induction of polymorphism. As far as we know, this is the first study that monitors the genotoxicity and somaclonal variations on Vanilla planifolia Jacks. ex Andrews under in vitro conditions and with a long-term exposure to the nanomaterial.

\section{Materials and Methods}

\subsection{In Vitro Establishment and Culture Conditions}

Stems of $20 \mathrm{~cm}$ length were cut from young $V$. planifolia plants kept under greenhouse conditions. The leaves were removed, and $2 \mathrm{~cm}$ length nodal segments were cut off for use as explants. These were washed with a toothbrush and a solution prepared with $1 \mathrm{~L}$ tap water and 2 drops of Tween-20 (Sigma-Aldrich Chemical Company, St. Louis, MO, USA) for $45 \mathrm{~min}$. The explants were transferred to a laminar flow hood and immersed for $30 \mathrm{~s}$ in $70 \%$ ethanol $(v / v)$ solution, then rinsed three times with sterile distilled water. The explants were immersed in sodium hypochlorite solutions of final 
concentrations 0.6 and $0.3 \%(v / v)$ for 10 and $5 \mathrm{~min}$, respectively; after that were rinsed three times with sterile distilled water. Explants were cultured in $2.2 \times 15 \mathrm{~cm}$ test tubes with $15 \mathrm{~mL}$ MS medium supplemented with $3 \mathrm{~g} / \mathrm{L}$ of sucrose without growth regulators. Culture medium $\mathrm{pH}$ was adjusted with $0.1 \mathrm{~N}$ sodium hydroxide until $\mathrm{pH}=5.8$. 0.25\% $(w / v)$, Phytagel (Sigma Chemical Company, St. Louis, MO, USA) was added as a gelling agent, and then it was autoclaved for $15 \mathrm{~min}$ at $120^{\circ} \mathrm{C}$. The explants were incubated at $24 \pm 2{ }^{\circ} \mathrm{C}, 16 \mathrm{~h}$ light photoperiod with $40 \mu \mathrm{mol} \mathrm{m}{ }^{-2} \cdot \mathrm{s}^{-1}$. After two subcultures of four weeks each, $2 \mathrm{~cm}$ length shoots were used for different treatments with AgNPs.

\subsection{Silver Nanoparticles (AgNPs)}

Commercial AgNPs formulation, Argovit ${ }^{\circledR}$, was obtained from Scientific-Production Centre Vector-Vita Ltd., Novosibirsk, Russia. Argovit ${ }^{\circledR}$ is a water suspension of AgNPs with an average size of $38 \pm 15 \mathrm{~nm}$ coated with polyvinylpyrrolidone (PVP). The supplier's specifications indicate a metallic content of $12 \mathrm{mg} / \mathrm{mL}$ with $188 \mathrm{mg} / \mathrm{mL}$ of coating agent to generate a 20\% AgNPs $(200 \mathrm{mg} / \mathrm{mL})$ suspension. AgNPs characterization was performed by Transmission Electron Microscopy (TEM, JEOL JEM-2010, Tokyo, Japan) and silver content determined by Inductively coupled plasma-optical emission spectroscopy (ICP-OES, Varian, Palo Alto, CA, USA) before using. Z-potential was determined in a Malvern Instruments Zetasizer Nano NS model DTS 1060 (Malvern Instruments, Worcestershire, UK) in triplicate.

\subsection{Effect of AgNPS on In Vitro Elongation and Rooting of V. planifolia}

Each experimental tube $(2.2 \times 15 \mathrm{~cm}$ test tubes $)$ contains two shoots of $2 \mathrm{~cm}$ length cultured with $20 \mathrm{~mL}$ MS medium without growth regulators, supplemented with $30 \mathrm{~g} / \mathrm{L}$ of sucrose and the corresponding concentrations of $\operatorname{AgNPs}(0,25,50,100$, and $200 \mathrm{mg} / \mathrm{L})$. Ten test tubes were used per treatment. Culture medium $\mathrm{pH}$ adjustment, autoclaving and culture conditions were the same as described above. After six weeks of culture, shoot length, roots number and length, and the number of leaves was evaluated for all treatments.

\subsection{Genotoxic Effect of AgNPs on V. planifolia}

To determine the possible genotoxic effect on Vanilla planifolia plantlets exposed to different treatments of AgNPs, the root tip chromosomal aberration assay of Vicia faba of the International Program on Chemical Safety (IPCS, WHO) [15] was used because of its simplicity, quickness, and inexpensiveness with respect to the procedures for the obtainment of reliable results.

\subsubsection{Fixation and Staining of Root Tips}

Roots' tips were fixed in a freshly prepared fixative solution containing three parts methanol and one-part of glacial acetic acid, this solution was kept at $4{ }^{\circ} \mathrm{C}$ until its use. For preparing the root tips smears, they were removed from the refrigerator and transferred to room temperature in distilled water for $5 \mathrm{~min}$. The root tips were then hydrolyzed with $1 \mathrm{~N} \mathrm{HCl}$ at $60{ }^{\circ} \mathrm{C}$ for $6-7 \mathrm{~min}$. After hydrolysis, the root tips were thoroughly washed with water several times and then stained with aceto-orcein stain. Aceto-orcein stain is prepared adding $1 \mathrm{~g}$ of Orcein (Sigma-Aldrich, St. Louis, MO, USA) powder to $55 \mathrm{~mL}$ of boiling acetic acid at $45 \%$ in constant stirring. Once cool, the solution was adjusted to $100 \mathrm{~mL}$ with distilled water. The final solution is filtered and ready to use. When staining was completed, (after 45-60 min) the root-tips were transferred to clean slides and the darkly stained tips containing the meristem were separated from the rest of the roots. Squash preparations were produced in $45 \%$ acetic acid.

\subsubsection{Scoring of Slides}

In V. planifolia chromosome aberration assay, slides were scored for chromatid and chromosome aberrations only in metaphase. Six hundred cells in metaphases per root-tip and a total of 3000 cells 
were used for each treatment to obtain the total number of chromosomal aberrations. The mitotic index was obtained by counting the number of mitotic cells in 3000 cells per treatment using an Olympus microscope (Shinjuku-ku, Tokyo, Japan). The mitotic index was calculated as the ratio of the number of dividing cells to the total number of cells, multiplied by 100 . The aberrations scored were chromatid breaks, lagging chromosomes, binucleated cells, and micronucleus.

\subsection{Effect of AgNPs on Somaclonal Variation}

\subsubsection{DNA Isolation}

Leaf samples from five randomly-selected shoots per treatment were used for DNA genomic extraction. The extraction was accomplished according to the CTAB (cetyl trimethylammonium bromide) method, described by Stewart and Via [16]. The integrity of the extracted DNA was verified in $1 \%$ agarose gel stained with $10 \mathrm{mg} / \mathrm{L}$ ethidium bromide. Quantity and purity of the DNA were evaluated by spectrophotometry (Genesys 10S UV-VIS, Thermo Scientific, Vernon Hills, IL, USA).

\subsubsection{ISSR-PCR Analysis}

Thirty primers were tested to screen the DNA polymorphism in V. planifolia, from which the nine primers showing best quality of amplification profile were selected (Table 1 ). The reactions were carried out in a final volume of $25 \mu \mathrm{L}$ containing $50 \mathrm{ng}$ of DNA template, 1 X PCR reaction buffer, $2.5 \mathrm{mM}$ of $\mathrm{MgCl}_{2}, 0.2 \mathrm{mM}$ of dNTPS, $0.2 \mu \mathrm{M}$ of primer and $1 \mathrm{U}$ of Taq DNA polymerase (Sigma-Aldrich Chemical Company, St. Louis, MO, USA). DNA amplification was performed in a MaxyGene thermocycler (Axygen, Tewksbury, MA, USA) using the following cycling program: one cycle at $94{ }^{\circ} \mathrm{C}$ for $4 \mathrm{~min}$; 35 cycles at $94{ }^{\circ} \mathrm{C}$ for $50 \mathrm{~s}, 45-62{ }^{\circ} \mathrm{C}$ (according to the primer) for $50 \mathrm{~s}$ and $72{ }^{\circ} \mathrm{C}$ for $90 \mathrm{~s}$; and a final extension at $72{ }^{\circ} \mathrm{C}$ for $10 \mathrm{~min}$. The amplification products were separated by electrophoresis on $3 \%$ agarose gels at $90 \mathrm{~V}$ for $90 \mathrm{~min}$ and stained with $10 \mathrm{mg} / \mathrm{L}$ ethidium bromide. A DNA ladder (50-10,000 bp, DirectLoad Wide Range DNA marker, Sigma-Aldrich Chemical Company, St. Louis, MO, USA) was used as a molecular weight marker. The gels were photographed under UV light, using a Gel Doc-It Imager photo-documentation system (UVP, Upland, CA, USA). For each treatment, the polymorphism (\%) was calculated.

Table 1. ISSR primers used for detecting somaclonal variation in V. planifolia.

\begin{tabular}{|c|c|c|c|c|c|}
\hline Primer & Sequence $\left(5^{\prime}-3^{\prime}\right)$ & ${ }^{\circ} \mathrm{Tm}\left({ }^{\circ} \mathrm{C}\right)^{2}$ & No. of Bands & Range $(b p)^{3}$ & Polymorphism (\%) \\
\hline UBC 809 & AGAGAGAGAGAGAGAGG & 45 & 10 & $300-2000$ & 30 \\
\hline Т 06 & AGAGAGAGAGAGAGAGGT & 50 & 9 & $300-1550$ & 66.66 \\
\hline UBC 840 & GAGAGAGAGAGAGAGAYT $^{1}$ & 50 & 8 & 200-1400 & 25 \\
\hline UBC 836 & AGAGAGAGAGAGAGAGYA $^{1}$ & 50 & 7 & $200-1550$ & 42.86 \\
\hline UBC 812 & GAGAGAGAGAGAGAGAA & 50 & 7 & $200-1400$ & 28.57 \\
\hline UBC 825 & АCACACACACACACACТ & 51 & 6 & $500-3000$ & 83.33 \\
\hline UBC 808 & AGAGAGAGAGAGAGAGC & 52 & 10 & $200-750$ & 60 \\
\hline Т 05 & CGTTGTGTGTGTGTGTGT & 54 & 8 & $300-2000$ & 25 \\
\hline C 07 & GAGAGAGAGAGAGAGAC & 56 & 7 & $300-1400$ & 71.43 \\
\hline
\end{tabular}

\subsection{Experimental Design and Statistical Analysis}

The experiment was conducted using a completely randomized design consisting of five treatments with three replications; each replication included ten test tubes. For genotoxic effect determinations, three samples were used. For each sample, 600 cells in metaphase were analyzed per root-tip and five root-tips per treatment. For all variables, except molecular data, an analysis of variance and Tukey's comparison of means test $(p \leq 0.05)$ were performed using SPSS statistical software (Version 11.5 for Windows Inc., Chicago, IL, USA). 


\section{Results and Discussion}

\subsection{Characterization of $A g N P S$}

The batch of the commercial AgNPs formulation (Argovit ${ }^{\circledR}$ ) employed in this work was completely characterized, and physicochemical characteristics are presented in Table 2. The AgNPs characterized by TEM showed a spherical form (form factor 0.82) with a roundness of 0.88 (Figure 1). Size interval of silver nanoparticles is in the range 1-80 nm. The analysis of the AgNPs' dimensions showed average diameters of $38 \pm 15 \mathrm{~nm}$. Silver content quantification determined by ICP-OES has shown a concentration of $12 \mathrm{mg} / \mathrm{mL}$ ). Other physicochemical parameters agree with those reported by the provider.

Table 2. Physicochemical characteristics of silver nanoparticles commercial batch used in this work.

\begin{tabular}{cc}
\hline Properties & Mean \\
\hline Metallic silver content & $12 \mathrm{mg} / \mathrm{L}$ \\
Form Factor (Spheroid) & 0.82 \\
Roundness & 0.88 \\
Size interval of metallic silver particles by TEM (nm) & $1-80$ \\
Average diameter by TEM (nm) & $38 \pm 15$ \\
Zeta potential (mV) & -15 \\
Surface plasmon resonance (nm) & 420 \\
\hline
\end{tabular}

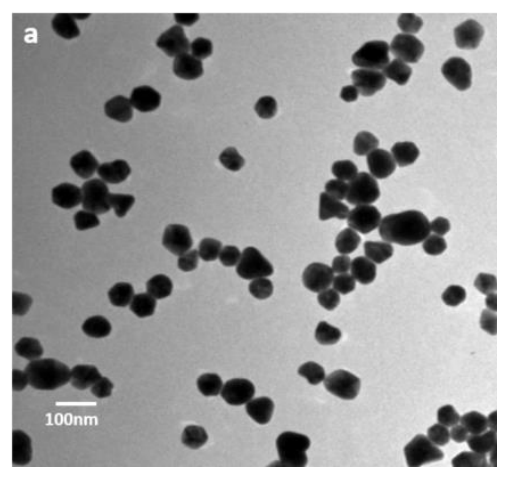

(a)

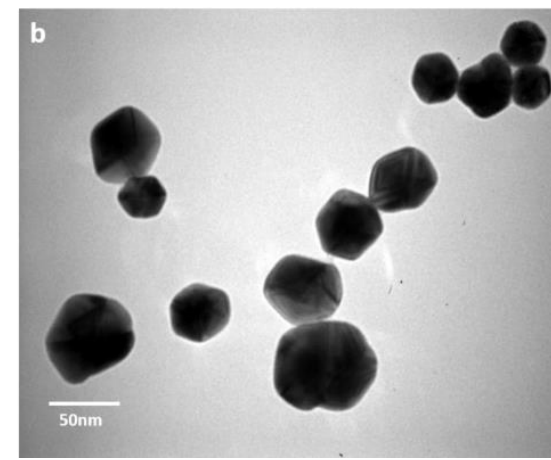

(b)

Figure 1. TEM image of AgNPs batch used in this work using different magnifications. (a) bar $=100 \mathrm{~nm}$, and $(\mathbf{b})$ bar $=50 \mathrm{~nm}$.

\subsection{Effects of AgNPs on Vanilla planifolia Physiological Parameters}

Administration of silver nanoparticles to Vanilla planifolia in vitro show a dose-dependent effect in different growth parameters such as shoot length and the number and length of roots. The shoot length, the number of leaves, and the number and length of the roots of plants exposed to 25 and $50 \mathrm{mg} / \mathrm{L}$ of AgNPs (1.5 and $3.0 \mathrm{mg} / \mathrm{L}$ of metallic silver) show no significant differences compared with the untreated plants used as a negative control group. On the other hand, the plants exposed to the higher concentrations of 100 and $200 \mathrm{mg} / \mathrm{L}$ of AgNPs (6 and $12 \mathrm{mg} / \mathrm{L}$ of metallic silver, respectively) show a minor number of roots with a decrease in its length and a decrease in the length of the shoots, but no difference regarding the number of leaves (Figure 2). 

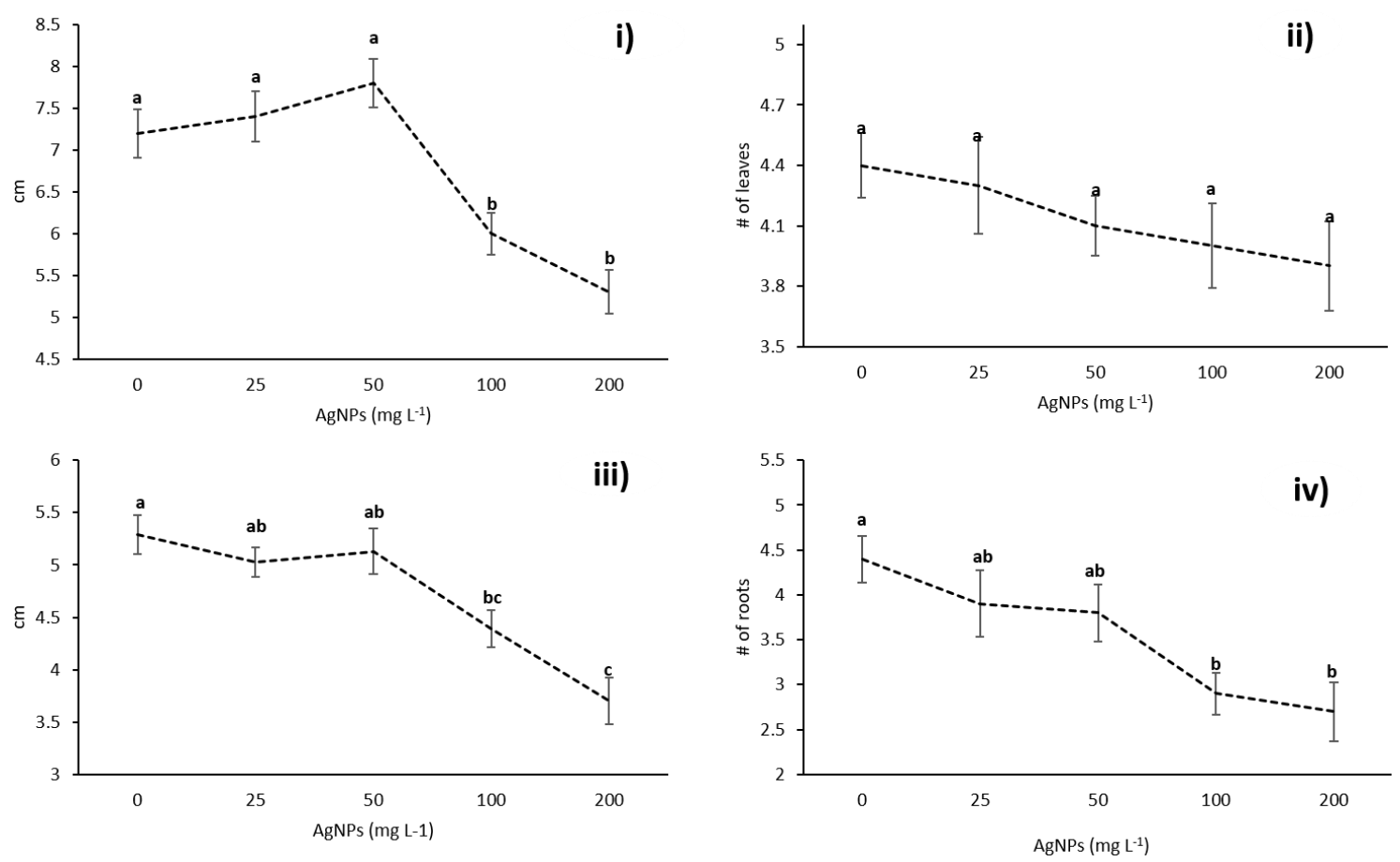

Figure 2. Effect of AgNPs on in vitro growth of V. planifolia after six weeks of culture. (i) Shoot length, (ii) number of leaves, (iii) root length, and (iv) number of roots. Different letters denote statistically significant differences according to Tukey's test $(p \leq 0.05)$.

As we showed in a previous paper [1], silver nanoparticles concentrations higher than $50 \mathrm{mg} / \mathrm{L}$ ( $3 \mathrm{mg} / \mathrm{L}$ of metallic silver) produce a very large amount of ROS that overwhelm the antioxidant system of the plant. The plants exposed to AgNPs concentrations of 100 and $200 \mathrm{mg} / \mathrm{L}$ (6 and $12 \mathrm{mg} / \mathrm{L}$ of metallic silver) showed an important decrease in number and length of roots, clearly appreciable by the naked eye as shown in Figure 3.

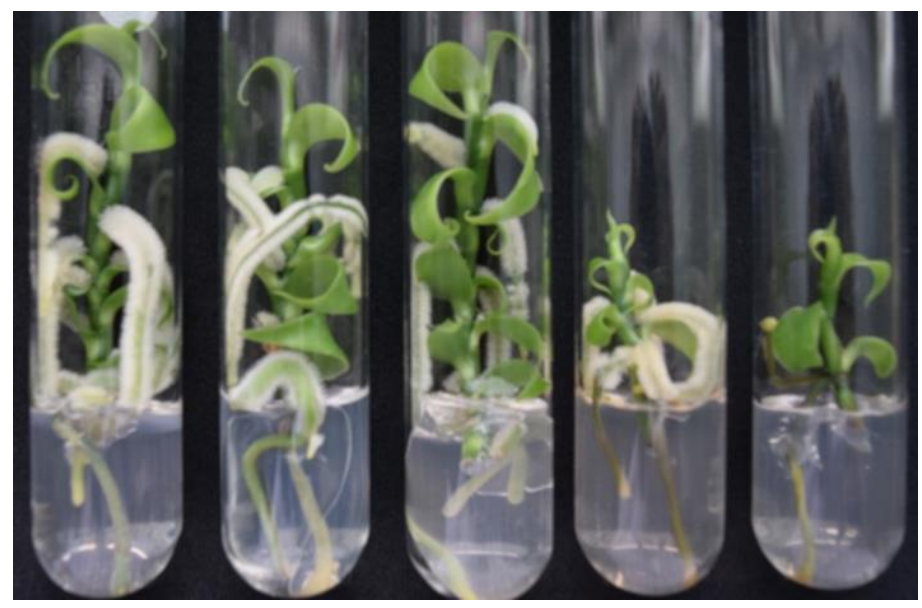

Figure 3. Effect of AgNPs on in vitro elongation and rooting of $V$. planifolia after six weeks of in vitro culture. From left to right $0,25,50,100$, and $200 \mathrm{mg} / \mathrm{L}$ of $\operatorname{AgNPs}(0,1.5,3,6$, and $12 \mathrm{mg} / \mathrm{L}$ of metallic silver).

\subsection{Cytotoxic and Genotoxic Effects}

Morphological changes described above are consistent with the dose-dependent behavior observed on cell proliferation, reported as the mitotic index in Table 3. The most important decrease in the mitotic index was observed between the AgNPs concentrations of 100 and $200 \mathrm{mg} / \mathrm{L}$ ( 6 and 
$12 \mathrm{mg} / \mathrm{L}$ of metallic silver). These concentrations also are associated with the higher production of ROS and lipid peroxidation [1], in turn, responsible for the damage that leads to cell death.

Table 3. Cytotoxic and Genotoxic effect of AgNPs on V. planifolia growth in vitro for six weeks.

\begin{tabular}{|c|c|c|c|c|c|c|c|}
\hline \multirow[t]{2}{*}{$\underset{\left(\mathrm{mg} \mathrm{L}^{-1}\right)^{1}}{\operatorname{AgNPs}}$} & \multirow[t]{2}{*}{$\begin{array}{l}\text { Cells in } \\
\text { Division }\end{array}$} & \multirow[t]{2}{*}{$\begin{array}{c}\text { Mitotic } \\
\text { Index (\%) }\end{array}$} & \multicolumn{4}{|c|}{ Aberration (\%) ${ }^{2}$} & \multirow{2}{*}{$\begin{array}{c}\text { Total } \\
\text { Aberration (\%) }\end{array}$} \\
\hline & & & CB & CF & BC & MN & \\
\hline 0 & $2582 \pm 92 *$ & $88.21 \pm 0.48^{*}$ & 0.03 & 0 & 0 & 0 & $0.03 \pm 0.00 *$ \\
\hline $25(1.5)$ & $2348 \pm 75$ * & $83.18 \pm 1.16^{*}$ & 0.10 & 0.08 & 0 & 0 & $0.18 \pm 0.06^{*}$ \\
\hline $50(3.0)$ & $2338 \pm 87$ * & $82.15 \pm 2.40 *$ & 0.30 & 0.50 & 0.17 & 0 & $0.97 \pm 0.03^{* *}$ \\
\hline $100(6.0)$ & $1786 \pm 99 * *$ & $60.35 \pm 0.90^{* *}$ & 1.5 & 1.0 & 0.16 & 1.5 & $4.16 \pm 0.17^{* * *}$ \\
\hline $200(12.0)$ & $1018 \pm 72^{* * *}$ & $33.53 \pm 1.91^{* * *}$ & 1.5 & 1.4 & 1.0 & 3.0 & $6.90 \pm 0.22^{* * * *}$ \\
\hline
\end{tabular}

${ }^{1}$ Values in brackets correspond to the metallic silver content in AgNPs formulation. ${ }^{2}$ The total number of cells counted was 3000. CB: Cells with bridges; CF: Chromosomal fragments; BC: Binucleated cells; MN: Micronuclei. Average values \pm standard error within a column followed by the same number of asterisks are not significantly different according to Tukey's test at $p \leq 0.05$.

Similar dose-dependent response regarding the number and the length of shoots and roots was found after the exposure of sugarcane to these AgNPs at the same concentrations. Furthermore, the adverse effect was also attributed to ROS overproduction that overwhelms the antioxidant response of the plant [17].

Activation of antioxidant response by exposure of plants to metal nanoparticles (MNP) was used to promote positive effects on callus induction, shoot regeneration, and growth [18]. However, ROS overproduction has been identified as one of the main mechanisms by which MNP including AgNPs produce phytotoxicity [19].

Increased concentrations of ROS not only affect the cellular viability of exposed plants, but may also affect the integrity of their genetic material. Genotoxic effects of AgNPs in plants is scarcely studied, that is why we explore the genetic damage that could be produced by the exposure of Vanilla planifolia to several concentrations of AgNPs through the identification of nuclear aberrations shown as cells with bridges (CB), chromosomal fragments (CF), binucleated cells (BN), and micronuclei (MN).

The lower concentrations of silver nanoparticles (25 and $50 \mathrm{mg} / \mathrm{L})$ do not generate significant damage in the genetic material neither as $\mathrm{CB}, \mathrm{CF}, \mathrm{BN}$ or $\mathrm{MN}$ compared with the control group, but an increase in the frequency of $\mathrm{CB}, \mathrm{CF}$, and $\mathrm{BN}$ were observed with the increment of silver nanoparticles concentrations without the presence of $\mathrm{MN}$.

On the other hand, the higher concentrations of AgNPs, 100 and $200 \mathrm{mg} / \mathrm{L}$ (6 and $12 \mathrm{mg}$ of metallic silver), administered to Vanilla planifolia continue with the observed tendency in the lower concentrations, increase aberrations in nuclear material as the concentration of AgNPs increase. The frequency of micronuclei registered was 1.5 and 3 with the exposure to $100 \mathrm{mg} / \mathrm{L}(6 \mathrm{mg} / \mathrm{L}$ of metallic silver) and $200 \mathrm{mg} / \mathrm{L}$ (12 mg/L of metallic silver), respectively.

As far as we know, this is the first study that reports the genotoxicity on Vanilla planifolia Jacks using the micronuclei test. Figure 4 shows the chromosomal aberrations found in root tip cells of Vanilla planifolia exposed to AgNPs $200 \mathrm{mg} / \mathrm{L}$ (12 mg/L of metallic silver).

Due to the lack of comparison data for this plant, we summarize in Table 4 some of the genotoxic effects reported in the literature for different AgNPs formulations administered to several plants. The summary is not intended to be exhaustive but useful for assessing the significance of the results related with chromatic aberrations found in this work. 
Table 4. DNA damage and/or genotoxic effects observed in diverse plants exposed to several exposure times and concentrations of different AgNPs formulations.

\begin{tabular}{|c|c|c|c|c|c|}
\hline Plant & $\begin{array}{c}\text { AgNPs Source and } \\
\text { Physicochemical Properties }\end{array}$ & $\begin{array}{l}\text { Active Component Concentration } \\
\text { (Metallic Silver Content) }\end{array}$ & Exposure Time and (AgNPs) Used & DNA Damage or Genotoxic Effect & Ref. \\
\hline Vanilla planifolia & $\begin{array}{l}\text { Commercial Vector-Vita PVP-AgNPs } \\
\text { Size: } 35 \pm 15 \mathrm{~nm} \text {, coating agent: PVP; } \zeta \\
\text { potential: }-15 \mathrm{mV} \text {; hydrodynamic } \\
\text { diameter: } 70 \mathrm{~nm}\end{array}$ & $\begin{array}{l}\text { Metallic silver content quantified by } \\
\text { ICP-OES } \\
1.5,3,6 \text {, and } 12 \mathrm{mg} / \mathrm{L} \text { of } \\
\text { metallic silver } \\
\begin{array}{l}13.9,27.8,55.6, \text { and } 111.25 \mu \mathrm{M} \text { of } \\
\text { metallic silver }\end{array}\end{array}$ & $\begin{array}{c}42 \text { days } \\
(1008 \mathrm{~h}) \\
25,50,100 \text {, and } 200 \mathrm{mg} / \mathrm{L} \text { of AgNPs }\end{array}$ & $\begin{array}{l}\text { A dose-dependent increase in the } \\
\text { frequency of cells with CA. } 1.5 \text { and } \\
3 \mathrm{MN} \text { were observed in } 3000 \text { counted } \\
\text { cells for the concentrations } 100 \text { and } \\
200 \mathrm{mg} / \mathrm{L} \text {, respectively }\end{array}$ & This work \\
\hline Allium cepa & $\begin{array}{l}\text { Commercial Sigma-Aldrich size: }<100 \\
\text { nm, purity: } 99.5 \% \text { trace metal basis, } \\
\text { coating agent: NR }\end{array}$ & NR & $\begin{array}{c}4 \mathrm{~h} \\
25,50,75, \text { and } 100 \mathrm{mg} / \mathrm{L}\end{array}$ & CA and cell disintegration. & [20] \\
\hline Vicia faba & $\begin{array}{l}\text { Commercial Ocean Nanotech LLC, size: } \\
60 \mathrm{~nm} \text {; purity: } 99.5 \% \text { trace metal basis, } \\
\text { coating agent: NR } \\
\text { Characterization made by the authors } \\
\text { Size: } 63 \pm 41 \mathrm{~nm}, \zeta \text { potential: }-33.2 \mathrm{mV}\end{array}$ & NR & $\begin{array}{c}4 \mathrm{~h} \text { of exposure and } 24 \mathrm{~h} \text { of recovery } \\
12.5,25,50 \text {, and } 100 \mathrm{mg} / \mathrm{L}\end{array}$ & $\begin{array}{l}\text { Dose-dependence increase in the } \\
\text { frequency of cells with CA and MN. } \\
\text { MN frequency with } 100 \mathrm{mg} / \mathrm{L} \text { of } \\
\text { AgNPs is triplicated compared with } \\
\text { control (control } 5.86 \pm 0.66 \text {; AgNPs } \\
100 \mathrm{mg} / \mathrm{L}: 18.4 \pm 0.75) .\end{array}$ & [21] \\
\hline Nicotiana tabacum & $\begin{array}{l}\text { Commercial Sigma-Aldrich Size: }<100 \\
\mathrm{~nm} \text {, purity: } 99.5 \% \text { trace metal basis, } \\
\text { coating agent: NR } \\
\text { Characterization made by the authors } \\
\text { size: TEM } 70-130 \mathrm{~nm} \text {, av. } \sim 125 \mathrm{~nm} \text {; } \\
\text { SEM: } 90-180 \mathrm{~nm} \text {, av. } 120 \mathrm{~nm} ; \zeta \text { potential: } \\
-4.86 \mathrm{mV}\end{array}$ & NR & $\begin{array}{c}24 \mathrm{~h} \\
25,50 \text {, and } 75 \mathrm{mg} / \mathrm{L}\end{array}$ & $\begin{array}{l}\text { No damage was observed in nuclei } \\
\text { isolated from shoots. Nuclei isolated } \\
\text { from roots exposed to } 50 \text { and } \\
75 \mu \mathrm{g} / \mathrm{mL} \text { shown DNA damage } \\
\text { determined by comet assay. } \\
\text { Dose-dependence for DNA damage. }\end{array}$ & [22] \\
\hline $\begin{array}{l}\text { Triticum durum Desf. } \\
\text { cv. Beni Sweif } 1\end{array}$ & $\begin{array}{l}\text { Synthesis, spherical, size: } \sim 20 \mathrm{~nm} \text {; } \\
\text { coating agent: NR }\end{array}$ & NR & $\begin{array}{c}\text { Soaked by } 24 \mathrm{~h} \text { in AgNPs solution } \\
\text { and germinated by a period of } 72 \text { and } \\
120 \mathrm{~h} \text {, respectively. } \\
\text { No concentrations reported } \\
\end{array}$ & $\begin{array}{l}\text { Time-dependent increase in the CA } \\
\text { and MN frequency }\end{array}$ & [23] \\
\hline $\begin{array}{l}\text { Hordeum vulgare L. } \\
\text { cv. Giza } 130\end{array}$ & $\begin{array}{l}\text { Synthesis, spherical, size: } \sim 20 \mathrm{~nm} \text {; } \\
\text { coating agent: NR }\end{array}$ & NR & $\begin{array}{c}\text { Soaked by } 24 \mathrm{~h} \text { in AgNPs solution } \\
\text { and germinated by a period of } 72 \text { and } \\
120 \mathrm{~h} \text {, respectively. } \\
\text { No concentrations reported }\end{array}$ & $\begin{array}{l}\text { Time-dependent increase in the } \mathrm{CA} \\
\text { and MN frequency }\end{array}$ & [23] \\
\hline $\begin{array}{l}\text { Pithophora oedogonia } \\
\text { (Mont.) } \\
\text { Wittrock/Chara } \\
\text { vulgaris Linn. }\end{array}$ & $\begin{array}{l}\text { Synthesis; size: } 10-15 \mathrm{~nm} \text {, coating } \\
\text { agent: NR }\end{array}$ & NR & $\begin{array}{l}5 \text { and } 10 \text { days } \\
0.9 \text { and } 1.5 \mathrm{mM}\end{array}$ & $\begin{array}{l}\text { CA observed with } 0.9 \mathrm{mM} \text { after } \\
\text { exposure of } 5 \text { days. Longer exposure } \\
\text { (10 days) or higher concentrations } \\
\text { enhance the magnitude of CA. }\end{array}$ & [24] \\
\hline Triticum aestivum $\mathrm{L}$. & $\begin{array}{l}\text { Green synthesis: Rhodophyta extraction } \\
+\mathrm{AgNO}_{3} \\
\text { Chemical synthesis: } \mathrm{NaOH}+\mathrm{AgNO}_{3}+ \\
\mathrm{PEG} \\
\text { No characterization data, coating } \\
\text { agent: NR }\end{array}$ & NR & $\begin{array}{c}8,16 \text {, and } 24 \mathrm{~h} \\
10,20,40 \text {, and } 50 \mathrm{mg} / \mathrm{L}\end{array}$ & $\begin{array}{l}\text { Both AgNPs showed concentration- } \\
\text { and time-dependent increase in the } \\
\text { frequency of cells with CA and MN. }\end{array}$ & [25] \\
\hline
\end{tabular}


Table 4. Cont.

\begin{tabular}{|c|c|c|c|c|c|}
\hline Plant & $\begin{array}{c}\text { AgNPs Source and } \\
\text { Physicochemical Properties }\end{array}$ & $\begin{array}{l}\text { Active Component Concentration } \\
\text { (Metallic Silver Content) }\end{array}$ & Exposure Time and (AgNPs) Used & DNA Damage or Genotoxic Effect & Ref. \\
\hline $\begin{array}{l}\text { Triticum aestivum } \mathrm{L} \text {. } \\
\text { cv. Blasco }\end{array}$ & $\begin{array}{l}\text { Commercial nanoComposix } \\
\text { Size: } 10 \mathrm{~nm} \text {, coating agent: PVP } \\
\text { Characterization made by the authors } \\
\text { Size: } 13.2 \mathrm{~nm}\end{array}$ & NR & $\begin{array}{l}\text { Soaked by } 4 \mathrm{~h} \text { in } 32 \mathrm{~mL} \text { of } 1 \text { and } \\
10 \mathrm{mg} / \mathrm{L} \text { PVP-AgNPs solution, } \\
\text { respectively. }\end{array}$ & $\begin{array}{l}\text { No differences between the genetic } \\
\text { polymorphism of roots treated with } \\
\text { AgNPs and control samples by AFLP. }\end{array}$ & [14] \\
\hline Allium cepa & $\begin{array}{l}\text { Synthesis } \\
\text { AgNPs-citrate, size: } 61.2 \pm 33.9 \mathrm{~nm} \text {; } \\
\text { TEM: rod-like; } \zeta \text { potential: } \\
-39.8 \pm 3.4 \mathrm{mV} \\
\text { AgNPs-PVP, size: } 9.4 \pm 1.3 \mathrm{~nm} \text {; TEM: } \\
\text { spherical; } \zeta \text { potential: }-4.8 \pm 0.6 \mathrm{mV} \\
\text { AgNPs-CTAB, size: } 5.6 \pm 2.1 \mathrm{~nm} \text {; TEM: } \\
\text { spherical; } \zeta \text { potential: } 42.5 \pm 2.7 \mathrm{mV}\end{array}$ & $\begin{array}{l}\text { Metallic silver content quantified by } \\
\text { ICP-MS for each sample } \\
25,50,75 \text {, and } 100 \mu \mathrm{M}\end{array}$ & $\begin{array}{c}72 \mathrm{~h} \\
25,50,75, \text { and } 100 \mu \mathrm{M}\end{array}$ & $\begin{array}{l}\text { No DNA damage was observed with } \\
\text { any of the AgNPs-citrate } \\
\text { concentrations employed. Increase in } \\
\text { tail DNA was recorded after } \\
\text { exposure to AgNPs-PVP at } 100 \mu \mathrm{M} \\
\text { concentration. AgNPs-CTAB } \\
\text { produces DNA damage only with } \\
50 \mu \mathrm{M} \text { concentration. }\end{array}$ & [26] \\
\hline $\begin{array}{l}\text { Tecomella undulata } \\
\text { (Roxb.) Seem. }\end{array}$ & NR & NR & $\begin{array}{c}16 \text { days } \\
(384 \mathrm{~h}) \\
30,60 \text {, and } 120 \mathrm{mg} / \mathrm{L}\end{array}$ & $\begin{array}{l}\text { More than } 30 \mathrm{mg} / \mathrm{L} \text { of AgNPs } \\
\text { decreases ACS } \\
\text { expression levels }\end{array}$ & [27] \\
\hline $\begin{array}{c}\text { Solanum } \\
\text { lycopersicum } \mathrm{L} .\end{array}$ & $\begin{array}{l}\text { Commercial Sigma-Aldrich (Catalog } \\
\text { number 576832) } \\
\text { Nanopowder, size: }<100 \mathrm{~nm} \text {, PVP as } \\
\text { dispersant, purity: } 99.5 \% \text { trace } \\
\text { metal basis }\end{array}$ & NR & $\begin{array}{c}14 \text { days } \\
(336 \mathrm{~h}) \\
10,20,40 \text {, and } 80 \mathrm{mg} / \mathrm{L}\end{array}$ & $\begin{array}{l}\text { GTS decreases as AgNPs } \\
\text { concentration increases. }\end{array}$ & [28] \\
\hline Lathyrus sativus L. & 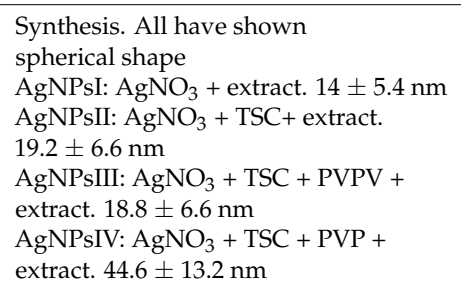 & NR & $\begin{array}{c}\text { Exposure for } 3 \mathrm{~h} \text { and recovery time of } \\
4,8,12 \text {, and } 24 \mathrm{~h} \\
1,5,10,20 \text {, and } 40 \mathrm{mg} / \mathrm{L}\end{array}$ & $\begin{array}{l}\text { Authors report that all AgNPs induce } \\
\text { genotoxic effects from the } \\
\text { concentration of } 1 \mathrm{mg} / \mathrm{L} \text {, } \\
\text { with exception of AgNPsIV which } \\
\text { induced genotoxicity only at the } \\
\text { higher concentration of } 40 \mathrm{mg} / \mathrm{L} \text {. }\end{array}$ & [29] \\
\hline
\end{tabular}



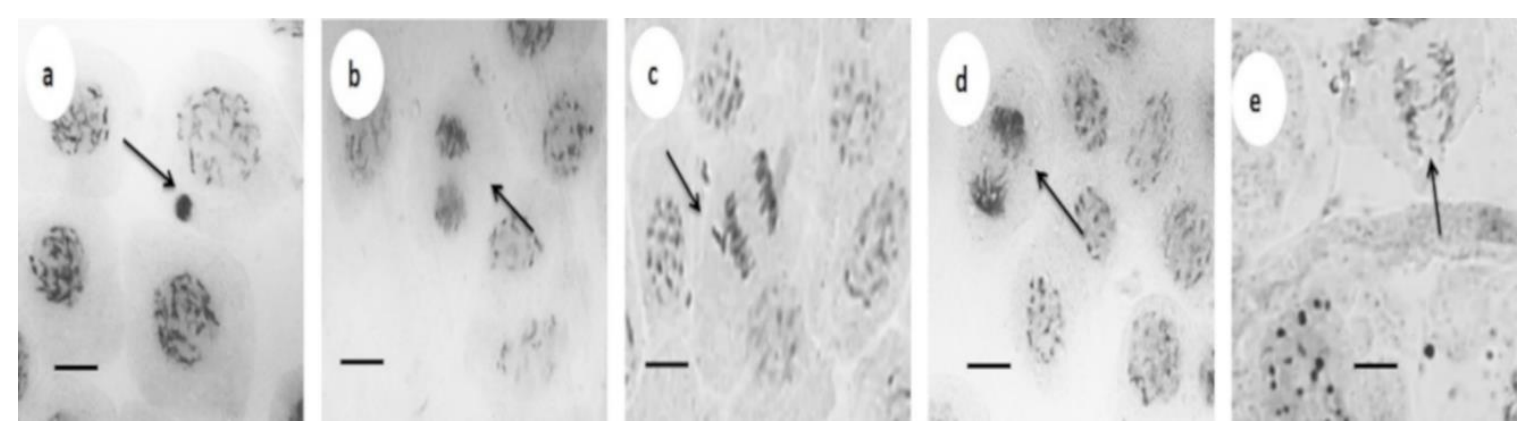

Figure 4. Chromosomal aberration and nuclear observed in root tips cells of V. planifolia at $200 \mathrm{mg} \mathrm{L}^{-1}$ of AgNPs after six weeks of in vitro culture. (a) Cell with micronucleus; (b) binucleated cell, (c) cell in anaphase with a chromosomal fragment, (d) cell in telophase with laggard, and (e) cell in anaphase with a bridge. Arrows indicate the produced damage in each case. Bar $=10 \mu \mathrm{m}$.

Table 4 shows that practically all studied formulations of AgNPs produce DNA damage in plants that have been exposed to these nanomaterials by different times and concentrations. In general, it could be established that a concentration- and time-dependent increase frequency of cells with chromatic aberrations (CA) and micronuclei (MN) was observed in plants exposed to AgNPs, independently of the treated plant or the AgNPs formulation employed.

The highest exposure time employed for the different AgNPs formulations compiled in Table 4, without including our results, is 10 days [24]. In all examples, chromatic aberrations or micronuclei appears with the highest concentrations and the effect increases over time, except for AgNPs-citrate formulation that after $72 \mathrm{~h}$ and $100 \mu \mathrm{M}$ of silver administered, do not show differences with the untreated control plants [26]. The same concentration-dependent behavior regarding chromatic aberrations induction was found in our study when plantlets of Vanilla planifolia were exposed to several similar concentrations of our AgNPs formulation but with a 14-fold higher exposure time. (42 days $=1008 \mathrm{~h})$.

Only one other report compiled in Table 4, besides ours, quantified silver content in their AgNP formulations [26]. The authors of this work evaluated the genotoxic damage induced by different formulations of AgNPs in the reference system Allium cepa [30], with similar concentrations than that we use in Vanilla planifolia. In this study, they found differences in the physiological and biochemical indicators such as ROS concentration, lipid peroxidation, and antioxidant response, mainly related with the size and coating of the three AgNPs formulations evaluated, AgNPs-citrate, AgNPs-PVP and AgNPs-CTAB. (PVP: poly(vinylpyrrolidone); CTAB: Cetyl trimethylammonium bromide).

Although it has been established that cytotoxic and in turn, the genotoxic effects depend on the size, coating, and exposure time $[9,18,31,32]$, we believe that content of silver is also a fundamental component that must be reported for each AgNPs formulation generated, since the metal is the main active component responsible of the effects produced in the biological systems. Thus, we consider that minimum characterization data of nanoparticles including size, the coating agent (if exist), exposure time and silver concentration of the stock suspension employed must be reported. This in order to systematize the evaluation of the cytotoxic and genotoxic effect produced by nanomaterials, in this particular case, AgNPs.

Once analyzed data compiled in Table 4, we can suggest that our AgNPs formulation despite producing a cytotoxic effect at doses of 100 and $200 \mathrm{mg} / \mathrm{L}$ ( 6 and $12 \mathrm{mg} / \mathrm{L}$ of metallic silver), does not produce an important damage that can be considered as genotoxic on Vanilla planifolia plantlets that have been exposed even to $200 \mathrm{mg} / \mathrm{L}$ of nanoparticles $(12 \mathrm{mg} / \mathrm{L}$ of metallic silver) for a quite long exposure time, 42 days. This is proposed considering that, despite the presence of DNA damage such as cells with bridges, binucleated cells, or chromosomal fragments, these errors can be solved by the cells. Then, the parameter that finally defines the irreversible genotoxic effect is the presence of micronuclei. In this sense, the increase of micronucleus in these plantlets after the long exposure 
time and concentrations employed could be considered as minimal comparing the effect observed in other systems. However, since the lack of positive genotoxicity control, this is only a suggestion. In our knowledge, this is the first report where cytotoxic and genotoxic parameters were determined after a very long exposure period. Definitely, further analysis must be done to study the real range of micronuclei, if it is possible to establish, for Vanilla planifolia in normal conditions and identify the magnitude of the damage due to the presence of AgNPs.

As we previously established, this AgNPs formulation was extremely effective to eliminate bacterial contamination with a concentration of 25 and $50 \mathrm{mg} / \mathrm{L}$ through a temporary immersion system without affectation of the plantlet. Additionally, with this AgNPs concentration, a hormetic effect was observed triggered by the increase of plantlet antioxidant response and an improvement in the capture and use of the nutrients [1]. Furthermore, in this work was identified that this concentration (50 mg/L or $3 \mathrm{mg} / \mathrm{L}$ of metallic silver) did not hinder shoot and root growth, without an important decrease on the mitotic index and with the absence of genotoxicity, all this after a very long-term exposure to AgNPs.

It is possible that promotion of growth through oxidative stress generation also promotes somaclonal variation due to the adaptation to the new in vitro growth conditions, which can be useful for increasing genetic variability of Vanilla planifolia crops, as was found for other systems, such as Anthurium [33] and apple [34], among others. Genetic improvement is not only important to satisfy raw material demands, but could also be useful for the preservation of the decimated wild population.

As far as we know, only three works reported the effect of AgNPs with respect to the induction of polymorphism or at the level of protein expression due to modifications in the genome with very different results $[14,27,28]$. In all systems, positive effects on plants were observed when exposed to low concentrations of AgNPs. However, is not possible to compare directly because the metallic silver content was not reported. On Triticum aestivum L. cv. Blasco no affectation was observed with the addition of $32 \mathrm{~mL}$ of $10 \mathrm{mg} / \mathrm{L}$ of AgNPs solution for $4 \mathrm{~h}$ [14]. A decrease in the genome template stability (GTS) was observed on Solanum lycopersicum L. treated with $10 \mathrm{mg} / \mathrm{L}$ or more of AgNPs after $336 \mathrm{~h}$ of exposure [28], which could improve the genetic variability of the species. Finally, lower expression of 1-aminocyclopropane-1-carboxylate synthase (ACS) - a key enzyme in ethylene biosynthesis-was observed on Tecomella undulata (Roxb.) Seem. with $30 \mathrm{mg} / \mathrm{L}$ after $384 \mathrm{~h}$ [27].

\subsection{Somaclonal Variation}

To know the capability of AgNPs formulation studied in the present work to induce somaclonal variation on Vanilla planifolia plantlets, an inter-simple sequence repeat (ISSR) analysis was performed. ISSR is a widely used method to identify genetic diversity in plants through changes in repeat units of the genome $[13,35]$. The analysis of the banding profiles (Table 1, Figure 5 and Figures S1-S8) revealed the existence of polymorphism after exposure to several concentrations of AgNPs evaluated in leaves collected from five different plants. A total of 72 fragments from the selected ISSR markers compiled in Table 1 were amplified. Figure 5 shows the band pattern amplified with UBC (University of British Columbia) primer UBC-825. The band pattern of the others primers can be consulted in the Supplementary information (Figures S1-S8).

Exposure to AgNPs increases the polymorphism of Vanilla planifolia plantlets. Somaclonal variation was found in all treatments, showing a dose-dependent behavior. Plantlets without exposure to AgNPs showed a polymorphism of $15.28 \%$. The polymorphism increases as AgNPs concentration does. The percentage of polymorphism observed was $18.06,20.83,23.61$, and $25 \%$ for plantlets exposed to 25, 50, 100, and $200 \mathrm{mg} / \mathrm{L}$ of AgNPs for six weeks, respectively. The polymorphism found in this work is wide lower than that reported by Divakaran and Ramírez-Mosqueda in the range of $71-76 \%$ [36,37] by indirect organogenesis without additional stimulus. This could be attributable to the adaptation response of plantlets to imposed regeneration conditions, with or without oxidative stress by the presence or absence of AgNPs. 

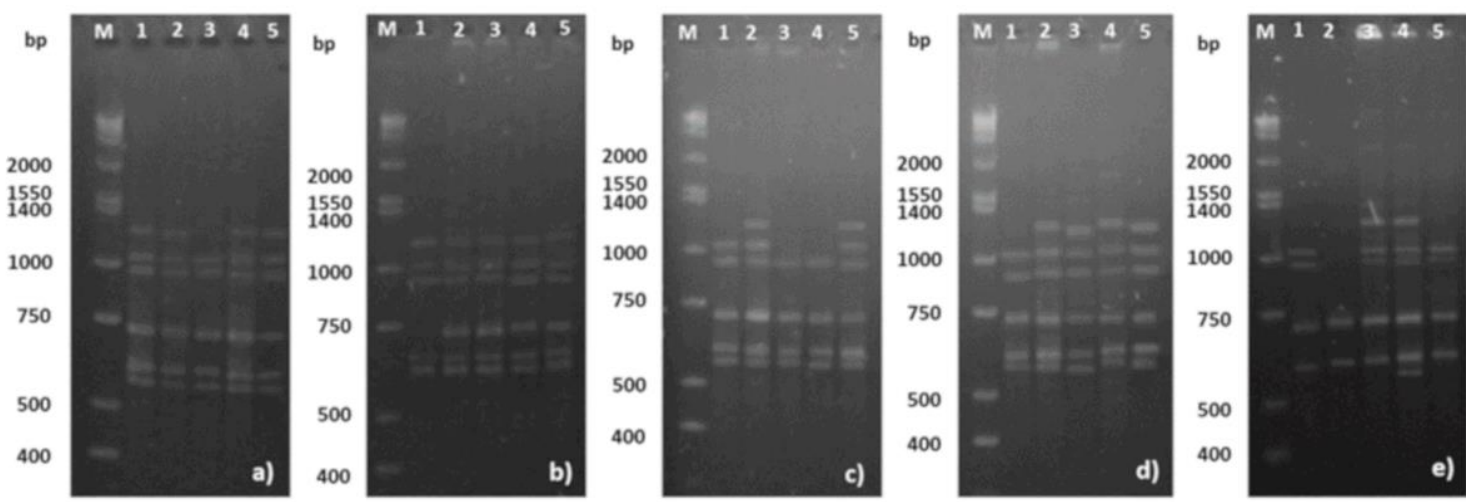

Figure 5. Electrophoresis pattern of ISSR banding profiles of five plants (1-5) of V. planifolia exposed to AgNPs for six weeks on in vitro culture. The amplification for UBC 825 primer corresponding to (a-e) $0,25,50,100$, and $200 \mathrm{mg} / \mathrm{L}$ of AgNPs, respectively. $\mathrm{M}=$ molecular mass marker $1 \mathrm{kbp}$ plus DNA ladder; $\mathrm{bp}=$ base pairs.

Vanilla planifolia is considered at risk and is under special protection by the Mexican Government (Mexico City, Mexico) (NOM-059-SEMARNAT-2010) [38]. Thus, these results could represent a new alternative for the optimization of protocols that using concentrations of AgNPs $\leq 50 \mathrm{mg} / \mathrm{L}$ did not hinder the growth of Vanilla planifolia plantlets while inducing polymorphism, but without affectations in the mitotic index and with the absence of genotoxicity.

\section{Conclusions}

In our knowledge, this is the first time that cytotoxic and genotoxic effect of a silver nanoparticles formulation has been studied on Vanilla planifolia plantlets. In addition, it is also the first report in which continuous exposure to silver nanoparticles is so long-Six weeks. Safe concentrations of this formulation, 25 and $50 \mathrm{mg} / \mathrm{L}$, were identified. At these concentrations, a small decrease in the mitotic index, from 88 to $82 \%$, and an increase in the frequency of cells with chromatic aberration, but without micronuclei, were observed. This damage could be considered negligible due to represents less than $1 \%$ of the total aberrations observed in 3000 cells. Even at the highest concentration ( $200 \mathrm{mg} / \mathrm{L})$, damage of genetic material is minimum considering very long exposure to AgNPs (six weeks) and the timeand concentration-dependence behavior observed for other AgNP formulations. Finally, AgNPs' safe concentrations promote the increase of polymorphism percentage, quite necessary to increase the genetic variability of this species considered at risk and under special protection. This work could represent a very important nanotechnological tool in the finding of alternatives to obtain large-scale and contaminant-free crops fundamental for several industries and, in this case, for the conservation of the species.

Supplementary Materials: The following are available online at http:/ /www.mdpi.com/2079-4991/8/10/754/s1.

Author Contributions: Conceptualization: J.J.B.-B., M.E.A.-G. and N.B.; data curation: J.L.S.-C., S.A.-A. and E.M.-E.; formal analysis: J.J.B.-B., J.L.S.-C., S.A.-A., E.M.-E., Y.T.-M. and J.C.G.-R; funding acquisition: N.B.; investigation: J.J.B.-B., J.L.S.-C., S.A.-A., E.M.-E. and M.E.A.-G.; methodology: J.J.B.-B., J.L.S.-C., S.A.-A. and E.M.E.; project administration: J.J.B.B. and N.B.; resources: A.P.; supervision: J.J.B.B.; validation: M.E.A.-G.; visualization: J.C.G.-R.; writing—original draft: J.J.B.-B., Y.T.-M. and J.C.G.-R.; writing—review and editing: J.C.G.-R.

Funding: This research was funded by Conacyt 293418 (Red Internacional de Bionanotecnología con Impacto en Medicina, Alimentación y Bioseguridad), Conacyt 294727 (Farmoquímicos) and Tomsk Polytechnic University Competitiveness Enhancement Program grant VIU-ISHBMT-196/2018. The APC was funded by Conacyt 293418.

Acknowledgments: The authors thank Conacyt 293418 (Red Internacional de Bionanotecnología) and 294727 (Farmoquímicos).

Conflicts of Interest: The authors declare no conflict of interest. 


\section{References}

1. Spinoso-Castillo, J.L.; Chavez-Santoscoy, R.A.; Bogdanchikova, N.; Pérez-Sato, J.A.; Morales-Ramos, V.; Bello-Bello, J.J. Antimicrobial and hormetic effects of silver nanoparticles on in vitro regeneration of vanilla (Vanilla planifolia Jacks. ex Andrews) using a temporary immersion system. Plant Cell Tissue Organ Cult. 2017, 129, 195-207. [CrossRef]

2. Wang, P.; Lombi, E.; Zhao, F.J.; Kopittke, P.M. Nanotechnology: A New Opportunity in Plant Sciences. Trends Plant Sci. 2016, 21, 699-712. [CrossRef] [PubMed]

3. Sarmast, M.K.; Salehi, H. Silver Nanoparticles: An Influential Element in Plant Nanobiotechnology. Mol. Biotechnol. 2016, 58, 441-449. [CrossRef] [PubMed]

4. Raja muthuramalingam, T.; Shanmugam, C.; Gunasekaran, D.; Duraisamy, N.; Nagappan, R.; Krishnan, K. Bioactive bile salt-capped silver nanoparticles activity against destructive plant pathogenic fungi through in vitro system. RSC Adv. 2015, 5, 71174-71182. [CrossRef]

5. Villamizar-Gallardo, R.; Cruz, J.F.O.; Ortíz, O.O. Fungicidal effect of silver nanoparticles on toxigenic fungi in cocoa. Pesqui. Agropecu. Bras. 2016, 51, 1929-1936. [CrossRef]

6. Moradpour, M.; Aziz, M.A. Establishment of in vitro Culture of Rubber (Hevea brasiliensis) from Field-derived Explants: Effective Role of Silver Nanoparticles in Reducing Contamination and Browning. J. Nanomed. Nanotechnol. 2016, 7, 375. [CrossRef]

7. Abdi, G.; Salehi, H.; Khosh-Khui, M. Nano silver: A novel nanomaterial for removal of bacterial contaminants in valerian (Valeriana officinalis L.) tissue culture. Acta Physiol. Plant. 2008, 30, 709-714. [CrossRef]

8. Mehrian, S.K.; De Lima, R. Nanoparticles cyto and genotoxicity in plants: Mechanisms and abnormalities. Environ. Nanotechnol. Monit. Manag. 2016, 6, 184-193. [CrossRef]

9. Yanga, J.; Cao, W.; Rui, Y. Interactions between nanoparticles and plants: Phytotoxicity and defense mechanisms. J. Plant Interact. 2017, 12, 158-169. [CrossRef]

10. Wang, J.; Koo, Y.; Alexander, A.; Yang, Y.; Westerhof, S.; Zhang, Q.; Schnoor, J.L.; Colvin, V.L.; Braam, J.; Alvarez, P.J.J. Phytostimulation of poplars and Arabidopsis exposed to silver nanoparticles and $\mathrm{Ag}^{+}$at sublethal concentrations. Environ. Sci. Technol. 2013, 47, 5442-5449. [CrossRef] [PubMed]

11. Nair, P.M.G.; Chung, I.M. Physiological and molecular level studies on the toxicity of silver nanoparticles in germinating seedlings of mung bean (Vigna radiata L.). Acta Physiol. Plant. 2015, 37, 1-11. [CrossRef]

12. Cabrera, G.L.; Rodriguez, D.M.G. Genotoxicity of soil from farmland irrigated with wastewater using three plant bioassays. Mutat. Res. Fundam. Mol. Mech. Mutagen. 1999, 426, 211-214. [CrossRef]

13. Wolfe, A.D. ISSR techniques for evolutionary biology. Methods Enzymol. 2005, 395, 134-144. [CrossRef] [PubMed]

14. Vannini, C.; Domingo, G.; Onelli, E.; De Mattia, F.; Bruni, I.; Marsoni, M.; Bracale, M. Phytotoxic and genotoxic effects of silver nanoparticles exposure on germinating wheat seedlings. J. Plant Physiol. 2014, 171, 1142-1148. [CrossRef] [PubMed]

15. Kanaya, N.; Gill, B.S.; Grover, I.S.; Murin, A.; Osiecka, R.; Sandhu, S.S.; Andersson, H.C. Vicia faba chromosomal aberration assay. Mutat. Res. Regul. Pap. 1994, 310, 231-247. [CrossRef]

16. Stewart, C.N., Jr.; Via, L.E. A rapid CTAB DNA isolation technique useful for RAPD fingerprinting and other PCR applications. Biotechniques 1993, 14, 748-751. [PubMed]

17. Bello-Bello, J.J.; Chavez-Santoscoy, R.A.; Lecona-Guzmán, C.A.; Bogdanchikova, N.; Salinas-Ruíz, J.; Gómez-Merino, F.C.; Pestryakov, A. Hormetic response by silver nanoparticles on in vitro multiplication of sugarcane (Saccharum spp. Cv. Mex 69-290) using a temporary immersion system. Dose-Response 2017, 15, 1-9. [CrossRef] [PubMed]

18. Kim, D.H.; Gopal, J.; Sivanesan, I. Nanomaterials in plant tissue culture: The disclosed and undisclosed. RSC Adv. 2017, 7, 36492-36505. [CrossRef]

19. Tripathi, D.K.; Shweta; Singh, S.; Singh, S.; Pandey, R.; Singh, V.P.; Sharma, N.C.; Prasad, S.M.; Dubey, N.K.; Chauhan, D.K. An overview on manufactured nanoparticles in plants: Uptake, translocation, accumulation and phytotoxicity. Plant Physiol. Biochem. 2017, 110, 2-12. [CrossRef] [PubMed]

20. Kumari, M.; Mukherjee, A.; Chandrasekaran, N. Genotoxicity of silver nanoparticles in Allium cepa. Sci. Total Environ. 2009, 407, 5243-5246. [CrossRef] [PubMed] 
21. Patlolla, A.K.; Berry, A.; May, L.; Tchounwou, P.B. Genotoxicity of silver nanoparticles in Vicia faba: A pilot study on the environmental monitoring of nanoparticles. Int. J. Environ. Res. Public Health 2012, 9, 1649-1662. [CrossRef] [PubMed]

22. Ghosh, M.; Manivannan, J.; Sinha, S.; Chakraborty, A.; Mallick, S.K.; Bandyopadhyay, M.; Mukherjee, A. In vitro and in vivo genotoxicity of silver nanoparticles. Mutat. Res. Genet. Toxicol. Environ. Mutagen. 2012, 749, 60-69. [CrossRef] [PubMed]

23. Abou-Zeid, H.M.; Moustafa, Y. Physiologycal and Cytogenetic Response of Wheat and Barley to Silver Nanopriming Treatment. Int. J. Appl. Biol. Pharm. Technol. 2014, 5, 150-163.

24. Dash, A.; Singh, A.P.; Chaudhary, B.R.; Singh, S.K.; Dash, D. Effect of Silver Nanoparticles on Growth of Eukariotic Green Algae. Nano-Micro Lett. 2012, 4, 158-165. [CrossRef]

25. Abdelsalam, N.R.; Abdel-Megeed, A.; Ali, H.M.; Salem, M.Z.M.; Al-Hayali, M.F.A.; Elshikh, M.S. Genotoxicity effects of silver nanoparticles on wheat (Triticum aestivum L.) root tip cells. Ecotoxicol. Environ. Saf. 2018, 155, 76-85. [CrossRef] [PubMed]

26. Cvjetko, P.; Milošić, A.; Domijan, A.M.; Vinković Vrček, I.; Tolić, S.; Peharec Štefanić, P.; Letofsky-Papst, I.; Tkalec, M.; Balen, B. Toxicity of silver ions and differently coated silver nanoparticles in Allium cepa roots. Ecotoxicol. Environ. Saf. 2017, 137, 18-28. [CrossRef] [PubMed]

27. Sarmast, M.K.; Niazi, A.; Salehi, H.; Abolimoghadam, A. Silver nanoparticles affect ACS expression in Tecomella undulata in vitro culture. Plant Cell Tissue Organ Cult. 2015, 121, 227-236. [CrossRef]

28. Çekiç, F.Ö.; Ekinci, S.; İnal, M.; Ünal, D. Silver nanoparticles induced genotoxicity and oxidative stress in tomato plants. Turkish J. Biol. 2017, 41, 700-707. [CrossRef]

29. Panda, K.K.; Achary, V.M.M.; Phaomie, G.; Sahu, H.K.; Parinandi, N.L.; Panda, B.B. Polyvinyl polypyrrolidone attenuates genotoxicity of silver nanoparticles synthesized via green route, tested in Lathyrus sativus L. root bioassay. Mutat. Res. Genet. Toxicol. Environ. Mutagen. 2016, 806, 11-23. [CrossRef] [PubMed]

30. Leme, D.M.; Marin-Morales, M.A. Allium cepa test in environmental monitoring: A review on its application. Mutat. Res. Rev. Mutat. Res. 2009, 682, 71-81. [CrossRef] [PubMed]

31. Aslani, F.; Bagheri, S.; Muhd Julkapli, N.; Juraimi, A.S.; Hashemi, F.S.G.; Baghdadi, A. Effects of engineered nanomaterials on plants growth: An overview. Sci. World J. 2014, 2014, 641759. [CrossRef] [PubMed]

32. McShan, D.; Ray, P.C.; Yu, H. Molecular toxicity mechanism of nanosilver. J. Food Drug Anal. 2014, 22, $116-127$. [CrossRef] [PubMed]

33. Da Silva, J.A.T.; Dobránszki, J.; Winarto, B.; Zeng, S. Anthurium in vitro: A review. Sci. Hortic. 2015, 186, 266-298. [CrossRef]

34. Dobránszki, J.; Teixeira da Silva, J.A. Micropropagation of apple-A review. Biotechnol. Adv. 2010, 28, 462-488. [CrossRef] [PubMed]

35. Rakoczy-Trojanowska, M.; Bolibok, H. Characteristics and a Comparison of Three Classes of Microsatellite-Based Markers and Their Application in Plants. Cell. Mol. Biol. Lett. 2004, 9, 221-238. [CrossRef] [PubMed]

36. Divakaran, M.; Babu, K.N.; Ravindran, P.N.; Peter, K.V.; Plant, A.J.; Res, S. Biotechnology for micropropagation and enhancing variations in Vanilla. Asian J. Plant Sci. Res. 2015, 5, 52-62.

37. Ramírez-Mosqueda, M.A.; Iglesias-Andreu, L.G. Indirect organogenesis and assessment of somaclonal variation in plantlets of Vanilla planifolia Jacks. Plant Cell Tissue Organ Cult. 2015, 123, 657-664. [CrossRef]

38. Secretaría de Medio Ambiente y Recursos Naturales. Protección Ambiental-Especies Nativas de México de Flora y Fauna Silvestres-Categorías de Riesgo y Especificaciones para su Inclusión, Exclusión o Cambio-Lista de Especies en Riesgo; Diario Oficial de la Federación: Mexico City, Mexico, 2010; pp. 1-64.

(C) 2018 by the authors. Licensee MDPI, Basel, Switzerland. This article is an open access article distributed under the terms and conditions of the Creative Commons Attribution (CC BY) license (http:/ / creativecommons.org/licenses/by/4.0/). 